\title{
Uji konsentrasi hambat minimum (KHM) ekstrak buah mengkudu (Morinda citrifolia L.) terhadap pertumbuhan Streptococcus mutans
}

\author{
1'Jecklin Makolit \\ ${ }^{2}$ Olivia A. Waworuntu \\ ${ }^{3}$ Michael A. Leman
}

\author{
${ }^{1}$ Kandidat Skripsi Program Studi Pendidikan Dokter Gigi \\ ${ }^{2}$ Bagian Mikrobiologi Fakultas Kedokteran \\ ${ }^{3}$ Program Studi Pendidikan Dokter Gigi Fakultas Kedokteran \\ Universitas Sam Ratulangi Manado \\ Email: jeclyn_jeclyn@yahoo.com
}

\begin{abstract}
Noni fruit (Morinda cittrifolia L.) is an herbal plant that contains antibacterial substances, inter alia acubin, lasperuloside, alizarin, and some antraquinons, that have been proved to inhibit the growth of Streptococcus mutans. This study was aimed to obtain the minimum inhibitory concentration (MIC) of noni fruit extract (Morinda citrifolia L.) against the growth of Streptococcus mutans. This was a true experimental study with a randomized pretest-posttest control group design. This study used a serial dilution method with turbidimetry and spectrophotometry tests. Noni fruit was extracted by using maceration method with $96 \%$ ethanol. Streptococcus mutans bacteria were obtained from pure stock of Microbiology Laboratory of Pharmacy Program Study, University of Sam Ratulangi Manado. The results showed that the MIC of noni fruit extract against the growth of Streptococcus mutans was at 50\% of concentration. Conclusion: The minimum inhibitory concentration of Morinda citrifolia L. extract against the growth of Streptococcus mutans was $50 \%$.
\end{abstract}

Keywords: noni fruit (Morinda citrifolia L.), Streptococcus mutans, MIC

\begin{abstract}
Abstrak: Buah mengkudu (Morinda citrifolia, L) merupakan tanaman herbal dengan kandungan bahan berkhasiat antibakterial seperti acubin, lasperuloside, alizarin, dan beberapa zat antraquinon yang terbukti dapat menghambat pertumbuhan Streptococcus mutans. Penelitian ini bertujuan untuk mengetahui konsentrasi hambat minimum (KHM) dari ekstrak buah mengkudu (Morinda citrifolia L.) terhadap pertumbuhan Streptococcus mutans. Jenis penelitian ialah eksperimental murni dengan randomized pretest-posttest control group design. Metode yang digunakan yaitu metode serial dilusi dengan metode pengujian turbidimetri dan spektrofotometri. Buah mengkudu diekstraksi dengan metode maserasi menggunakan pelarut etanol 96\%. Bakteri Streptococcus mutans diambil dari stok bakteri murni Laboratorium Mikrobiologi Program Studi Farmasi Fakultas MIPA Universitas Sam Ratulangi. Hasil penelitian menunjukkan bahwa KHM ekstrak buah mengkudu terhadap pertumbuhan Streptococcus mutans pada konsentrasi 50\%. Simpulan: Konsentrasi hambat minimum ekstrak buah mengkudu (Morinda citrifolia L.) terhadap pertumbuhan Streptococcus mutans pada konsentrasi $50 \%$.
\end{abstract}

Kata kunci: buah mengkudu (Morinda citrifolia L.), Streptococcus mutans, KHM

Kesehatan rongga mulut merupakan bagian yang terpenting dalam tubuh manusia karena rongga mulut merupakan tempat masuknya makanan dan minuman. Saat rongga mulut tidak dijaga kebersihannya maka akan mengakibatkan penimbunan 
plak yang jika dibiarkan akan menjadi karies gigi. ${ }^{1}$

Karies gigi merupakan proses patologik multifaktorial yang terjadi di jaringan keras gigi seperti email, dentin, dan sementum. Karies gigi terjadi sebagai akibat adanya interaksi faktor genetik, mikroorganisme, lingkungan dalam rongga mulut, dan kebiasaan hidup dari pejamu. ${ }^{2}$ Menurut Riskesdas tahun 2013, prevalensi karies gigi atau indeks DMF-T di Indonesia ialah 4.6; dengan kata lain, setiap orang memiliki setidaknya 4-5 gigi yang rusak. Sementara itu, untuk daerah Sulawesi Utara, indeks DMF-T ialah 5,4, yang berarti setiap orang memiliki lima atau lebih gigi yang bermasalah. ${ }^{3}$ Penyebab utama dari karies gigi ialah bakteri Streptococcus mutans.

Streptococcus mutans menyebabkan gigi berlubang di seluruh dunia tersering dibandingkan dengan semua streptococcus oral yang lain. ${ }^{4}$ Banyak cara yang dapat dilakukan untuk mencegah karies gigi, diantaranya penggunaan fluor, kontrol bakteri, diet, dan penggunaan fissure sealant. Pengobatan dengan cara kimiawi juga dapat dilakukan yaitu dengan menggunakan obat antibiotik namun obat antibiotik mempunyai efek negatif yaitu dapat mengakibatkan resistensi; oleh karena itu diperlukan obat herbal sebagai pengganti dari antibiotik tersebut. ${ }^{5}$

Saat ini telah banyak penelitian yang meneliti tentang tanaman herbal sebagai antibakterial. Beberapa penelitian yang pernah dilakukan menunjukkan bahwa kandungan tanaman mengkudu berkhasiat sebagai antibakterial, seperti acubin, lasperuloside, alizarin, dan beberapa zat antraquinon. Zat aktif ini dapat menghambat kinerja bakteri atau bersifat bakteriostatik. Penelitian sebelumnya oleh Malinggas mengenai uji daya hambat ekstrak buah mengkudu (M. citrifolia L.) terhadap pertumbuhan Streptococcus mutans in vitro, menyatakan bahwa tanaman mengkudu memiliki daya hambat terhadap bakteri Streptococcus mutans namun belum pernah ada penelitian mengenai kadar hambat minimum (KHM) ekstrak buah mengkudu terhadap bakteri penyebab karies gigi. ${ }^{6}$

Penelitian ini memberikan informasi mengenai KHM ekstrak buah mengkudu terhadap pertumbuhan bakteri Streptococcus mutans sehingga dapat dijadikan sebagai acuan pustaka untuk penelitian selanjutnya.

\section{BAHAN DAN METODE PENELITIAN}

Jenis penelitian ini ialah eksperimental laboratorium dengan randomized pretestposttest control group design. Penelitian ini dilaksanakan di Laboratorium Fitokimia dan Laboratorium Mikrobiologi Program Studi Farmasi Fakultas MIPA Universitas Sam Ratulangi selama bulan SeptemberOktober 2016. Subjek dalam penelitian ini ialah bakteri biakan murni Streptococcus mutans dari yang diperoleh di Laboratorium Mikrobiologi Program Studi Farmasi Fakultas MIPA Universitas Sam Ratulangi Manado.

Pada penelitian ini metode yang digunakan ialah metode serial dilusi atau pengenceran bertingkat dengan perbandingan 1:2(w/v). Metode pengujian menggunakan turbidimetri dan spektrofotometer UV-Vis.

Pembuatan media peremajaan bakteri menggunakan nutrient agar (NA). Selain itu digunakan juga media Brain Heart Infusion Broth (BHI-B), larutan baku McFarland 1 yang terdiri atas dua komponen yaitu larutan $\mathrm{BaCl} 2$ 1,175\% dan $\mathrm{H} 2 \mathrm{SO} 4$ 1\%. Nilai absorban larutan baku McFarland 1 setara jumlah sel bakteri dengan kepadatan $0,3 \times 10^{9}$ bakteri $/ \mathrm{ml}$.

Peremajaan bakteri Streptococcus mutans yang disimpan di media agar diambil dengan menggunakan jarum ose steril, lalu ditanamkan pada media agar miring dengan cara menghapus, kemudian diinkubasi selama 1x24 jam. Bakteri yang telah diremajakan pada media agar miring, kemudian diambil koloninya dari media agar miring dengan menggunakan jarum ose steril, dimasukkan ke dalam media BHI-B dalam tabung reaksi kemudian diinkubasi 1 x 24 jam. Setelah itu dilakukan pembuatan suspensi Streptococcus mutans sesuai dengan standar kekeruhan 
McFarland 1. Jika media BHI-B kelihatan lebih keruh dari larutan McFarland 1 tambahkan larutan salin sedikit demi sedikit kedalam media BHI-B sehingga kekeruhanya sesuai dengan kekeruhan standar McFarland 1.

Sebanyak 11 tabung reaksi steril disiapkan. Setiap tabung uji diberi label 19, kemudian tabung 10 diberi label $\mathrm{K}(+)$ yang merupakan kontrol positif, yaitu tabung yang berisi Streptococcus mutans setara dengan standar kekeruhan McFarland 1. Tabung 11 diberi label K(-) yang merupakan kontrol negatif, yaitu tabung berisi ekstrak buah mengkudu dengan konsentrasi $100 \%$. Tabung 1 diisi sebanyak $4 \mathrm{ml}$ konsentrasi $100 \%$ ekstrak buah mengkudu .Tabung 2-9 diisi dengan 2 ml media cair BHI.Kemudian ambil $2 \mathrm{ml}$ larutan dari tabung 1, dimasukkan ke dalam tabung 2, dicampur hingga homogen sehingga didapat konsentrasi 50\%. Hal yang sama dilakukan hingga tabung 9 .

Untuk pengujian menggunakan turbidimetri, setelah media tabung perlakuan diinkubasi selama 1x24 jam, semua tabung tersebut dilihat kekeruhannya secara visual. Bila kekeruhan masing-masing tabung masih setara atau lebih keruh dari tabung $\mathrm{K}(+)$ yang berisi suspensi bakteri Streptococcus mutans sesuai standar kekeruhan McFarland 1 berarti bakteri masih dapat bertumbuh, tetapi bila larutan dalam tabung terlihat mulai lebih jernih daripada tabung $\mathrm{K}(+)$ berarti pertumbuhan bakteri mulai terhambat. Hal inilah yang menunjukkan konsentrasi hambat minimum (KHM).

Pengukuran menggunakan spektrofotometer sesudah media tabung perlakuan diinkubasi selama 1x24 jam. Semua tabung perlakuan tersebut diukur lagi nilai absorbannya dengan spektrofotometer sebagai nilai absorban akhir. Jika nilai absorban akhir (sesudah inkubasi) masingmasing tabung lebih besar dari nilai absorban awal (sebelum inkubasi), maka disimpulkan bahwa masih terjadi partumbuhan bakteri. Namun, jika sebaliknya tidak terdapat perubahan nilai absorban antara nilai absorban akhir dengan absorban awal, atau nilai absorban akhir lebih kecil dari nilai absorban awal, maka disimpulkan bahwa pertumbuhan bakteri dihambat. Kadar hambat minimum ditentukan dengan konsentrasi ekstrak terkecil pada tabung perlakuan yang sudah mulai menghambat pertumbuhan bakteri.

\section{HASIL PENELITIAN}

Penelitian ini dilakukan di Laboratorium Farmasi Fakultas MIPA Universitas Sam Ratulangi dan diperoleh data tentang KHM ekstrak buah mengkudu terhadap Streptococcus mutans, yang dilihat menggunakan metode turbidimetri dan spektrofotometer UV-Vis.

\section{Hasil turbidimetri}

Pengujian menggunakan metode turbidimetri dilakukan dengan tiga kali perlakuan. Perlakuan pertama menunjukkan KHM terlihat pada konsentrasi 6,25\% (Gambar 1). Hal yang sama juga terjadi pada perlakuan ke-2 dan ke-3 yaitu pada konsentrasi $6,25 \%$ tabung mulai jernih dan selanjutnya larutan pada tabung semakin jernih pada konsentrasi 3,125\%, 1,56\%, $0,78 \%$, dan $0,39 \%$. Melalui tiga perlakuan tersebut kadar hambat minimum ekstrak buah mengkudu terhadap pertumbuhan Streptococcus mutans terdapat pada konsentrasi 6,25\% (Gambar 2 dan 3). Tabel 1 memperlihatkan hasil pengujian menggunakan metode turbidimetri dari ekstrak buah mengkudu terhadap pertumbuhan Streptococcus mutans.

\section{Hasil spektrofotometer UV-Vis}

Pengujian kedua menggunakan spektrofotometer UV-Vis dengan mengukur nilai kekeruhan (nilai absorbansi) dan dilakukan tiga kali perlakuan. Pengukuran ini dilakukan menggunakan 11 tabung dimana tabung 1-9 berisi ekstrak buah mengkudu dengan berbagai konsentrasi, tabung 10 berisi kontrol positif, dan tabung 11 berisi kontrol negatif. Hasil pengukuran spektrofotometer UV-Vis dapat dilihat pada Tabel 2. Pada konsentrasi $50 \%$ telah terjadi penurunan nilai absorbansi, kemudian pada 
konsentrasi $25 \%$ terjadi kenaikan nilai absorbansi hingga konsentrasi paling akhir 0,39\% dengan demikian konsentrasi $50 \%$ ditetapkan sebagai KHM ekstrak buah mengkudu terhadap pertumbuhan Streptococcus mutans.

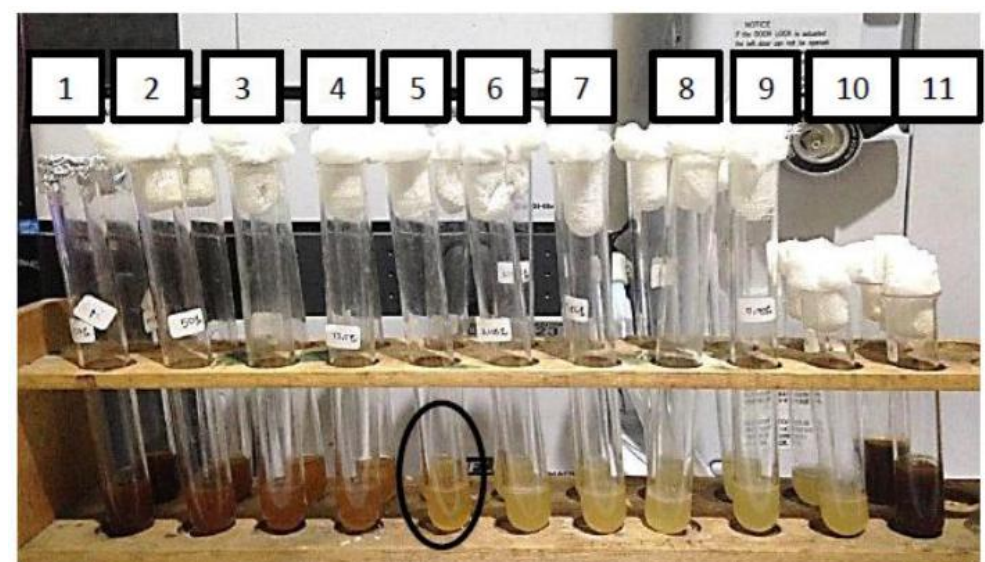

Gambar 1. Perlakuan 1 uji KHM ekstrak buah mengkudu (Morinda citrifolia L.) terhadap pertumbuhan Streptococcus mutans (perlakuan pertama) dengan metode turbidimetri

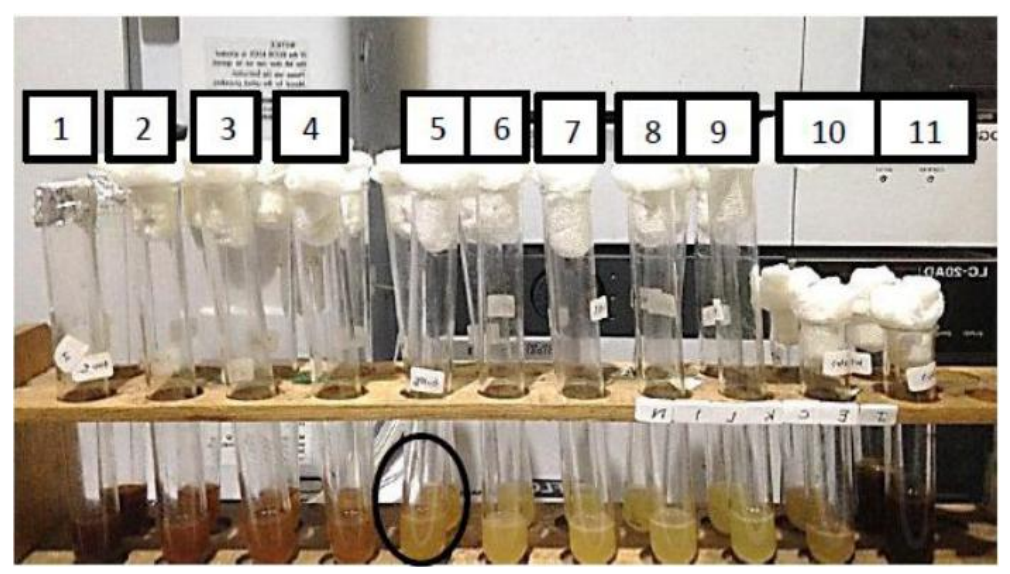

Gambar 2. Perlakuan 2 uji KHM ekstrak buah mengkudu (Morinda citrifolia L.) terhadap pertumbuhan Streptococcus mutans (perlakuan kedua) dengan metode turbidimetri

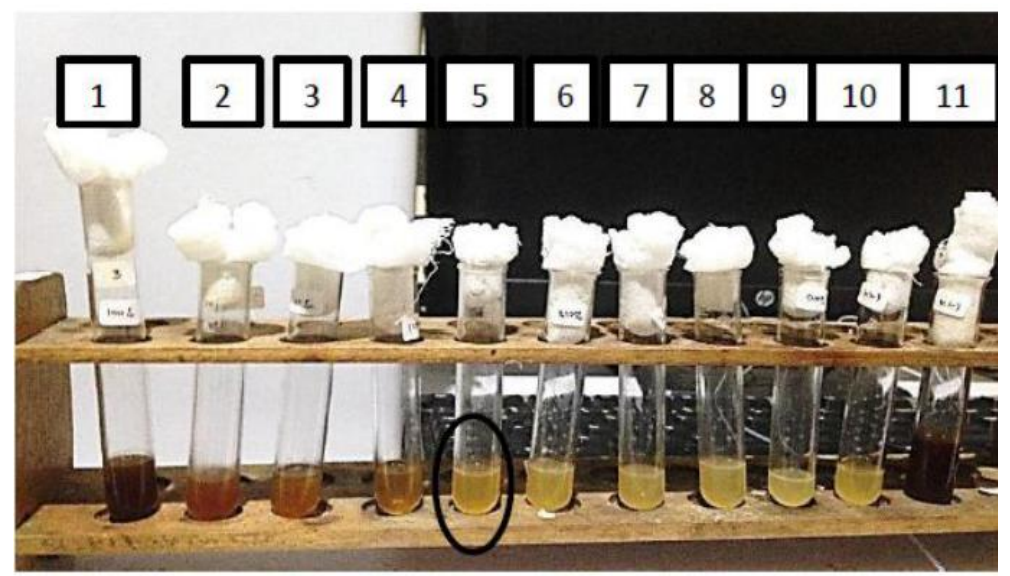

Gambar 3. Perlakuan 3 uji KHM ekstrak buah mengkudu (Morinda citrifolia L.) terhadap pertumbuhan Streptococcus mutans (perlakuan kedua) dengan metode turbidimetri 
Tabel 1. Hasil pengujian menggunakan metode turbidimetri dari ekstrak buah mengkudu terhadap pertumbuhan Streptococcus mutans

\begin{tabular}{ccccc} 
Nomor & $\begin{array}{c}\text { Konsentrasi ekstrak buah } \\
\text { mengkudu }\end{array}$ & \multicolumn{3}{c}{ Hasil } \\
\cline { 3 - 5 } & \begin{tabular}{c} 
Morinda citrifolia $\mathbf{L}$.) \\
\cline { 3 - 5 }
\end{tabular} & $\begin{array}{c}\text { Perlakuan } \\
\text { pertama }\end{array}$ & $\begin{array}{c}\text { Perlakuan } \\
\text { kedua }\end{array}$ & $\begin{array}{c}\text { Perlakuan } \\
\text { ketiga }\end{array}$ \\
\hline 1 & $100 \%$ & + & + & + \\
2 & $50 \% \%$ & + & + & + \\
3 & $25 \%$ & + & + & + \\
4 & $12,5 \%$ & - & - & - \\
$\mathbf{5}$ & $\mathbf{6 , 2 5 \%}$ & - & - & - \\
6 & $3,125 \%$ & - & - & - \\
7 & $1,56 \%$ & - & - & - \\
8 & $0,78 \%$ & - & - & - \\
9 & $0,39 \%$ & - & - & - \\
10 & $\mathrm{~K}(+)$ & + & + & + \\
11 & $\mathrm{~K}(-)$ & - & - & - \\
\hline
\end{tabular}

Keterangan: Tanda "+" menunjukkan larutan di dalam tabung terlihat keruh yang berarti bahwa bakteri Streptococcus mutans masih bertumbuh; sedangkan tanda "-“ menunjukkan larutan di dalam tabung terlihat jernih yang berarti bahwa pertumbuhan bakteri Streptococcus mutans terhambat.

Tabel 2. Hasil pengujian menggunakan spektrofotometer UV-Vis ekstrak buah mengkudu terhadap pertumbuhan Streptococcous mutans

\begin{tabular}{|c|c|c|c|c|c|c|c|c|c|}
\hline \multirow{3}{*}{$\begin{array}{c}\text { Konsentrasi } \\
\text { ekstrak } \\
\text { buah } \\
\text { mengkudu } \\
\text { (Morinda } \\
\text { citrifolia } \mathrm{L} .)\end{array}$} & \multicolumn{8}{|c|}{ Hasil } & \multirow[t]{3}{*}{ Ket. } \\
\hline & \multicolumn{2}{|c|}{ Perlakuan I } & \multicolumn{2}{|c|}{ Perlakuan II } & \multicolumn{2}{|c|}{ Perlakuan III } & \multicolumn{2}{|c|}{ Rerata } & \\
\hline & $\begin{array}{l}\text { Sebelum } \\
\text { inkubasi }\end{array}$ & $\begin{array}{l}\text { Sesudah } \\
\text { inkubasi }\end{array}$ & $\begin{array}{l}\text { Sebelum } \\
\text { inkubasi }\end{array}$ & $\begin{array}{l}\text { Sesudah } \\
\text { inkubasi }\end{array}$ & $\begin{array}{l}\text { Sebelum } \\
\text { inkubasi }\end{array}$ & $\begin{array}{l}\text { Sesudah } \\
\text { inkubasi }\end{array}$ & $\begin{array}{l}\text { Sebelum } \\
\text { inkubasi }\end{array}$ & $\begin{array}{l}\text { Sesudah } \\
\text { inkubasi }\end{array}$ & \\
\hline $100 \%$ & 2.536 & 2.510 & 2.446 & 2.388 & 2.348 & 2.371 & 2.443 & 2.423 & Turun \\
\hline $\mathbf{5 0 \%}$ & 1.397 & 1.359 & 1.427 & 1.447 & 1.405 & 1.409 & 1.409 & 1.405 & Turun \\
\hline $25 \%$ & 0.840 & 0.884 & 0.755 & 0.778 & 0.765 & 0.790 & 0.786 & 0.817 & Naik \\
\hline $12,5 \%$ & 0.505 & 0.521 & 0.469 & 0.469 & 0.444 & 0.496 & 0.472 & 0.493 & Naik \\
\hline $6,25 \%$ & 0.305 & 1.401 & 0.291 & 1.288 & 0.285 & 1.410 & 0.293 & 1.366 & Naik \\
\hline $3,125 \%$ & 0.219 & 1.808 & 0.205 & 1.896 & 0.208 & 1.893 & 0.210 & 1.865 & Naik \\
\hline $1,56 \%$ & 0.176 & 1.916 & 0.177 & 2.023 & 0.176 & 1.965 & 0.176 & 1.968 & Naik \\
\hline $0,78 \%$ & 0.156 & 1.923 & 0.140 & 1.971 & 0.140 & 1.834 & 0.145 & 1.909 & Naik \\
\hline $0,39 \%$ & 0.160 & 1.705 & 0.128 & 1.795 & 0.130 & 0.352 & 0.139 & 1.284 & Naik \\
\hline $\mathrm{K}(+)$ & 0.528 & 2.025 & 0.612 & 0.751 & 0.572 & 2.046 & 0.570 & 1.607 & Naik \\
\hline $\mathrm{K}(-)$ & 2.707 & 2.533 & 2.693 & 2.783 & 2.702 & 2.844 & 2.700 & 2.72 & Naik \\
\hline
\end{tabular}

Keterangan: "Naik" menunjukkan nilai absorbansi setelah inkubasi > nilai absorbansi sebelum inkubasi, yang berarti bahwa terdapat pertumbuhan bakteri; sedangkan "Turun" menunjukkan nilai absorbansi setelah inkubasi $\leq$ nilai absorbansi sebelum inkubasi, yang berarti bahwa pertumbuhan bakteri terhambat.

\section{BAHASAN}

Pada penelitian ini dilakukan uji kadar hambat minimum ekstrak buah mengkudu terhadap pertumbuhan
Streptococcus mutans dengan menggunakan pengenceran bertingkat perbandingan $1: 2(\mathrm{w} / \mathrm{v})$ yaitu $100 \%, 50 \%, 25 \%, 12,5 \%, 6,25 \%, 3,125 \%$, $1,56 \%, 0,78 \%$, dan $0,39 \% .^{7}$ Pada penelitian 
ini dilakukan dua jenis pengujian, yaitu dengan melihat nilai kekeruhan secara visual disebut uji turbidimetri dan pengukuran nilai absorbansi menggunakan spektrofotometer UV-Vis.

Melalui uji turbidimetri dengan penglihatan secara kasat mata sebanyak 3 kali perlakuan, didapatkan konsentrasi 12,5\% merupakan kadar hambat minimum ekstrak buah mengkudu terhadap pertumbuhan Streptococcus mutans. Perlakuan dilakukan setelah diinkubasi selama 24 jam.

Dengan metode pengujian secara visual (turbidimetri) sudah bisa ditentukan KHM namun metode pengujian secara visual (turbidimetri) memiliki kelemahan yaitu mata manusia pada saat melakukan pengamatan kekeruhan tidak bisa membedakan antara sel bakteri yang hidup dengan sel bakteri yang mati dan larutan bisa mencapai warna yang pekat; oleh sebab itu hasil pengamatan kurang akurat. Dengan demikian perlu dilakukan pengujian lebih lanjut dengan cara mengukur nilai absorbansi menggunakan spektrofotometer UV-Vis agar lebih akurat. $^{7}$

Pengukuran menggunakan spektrofotometer UV-Vis dilakukan sebelum dan sesudah inkubasi 24 jam yang dilihat melalui selisih hasil pengukuran nilai absorbansi sebelum dan sesudah inkubasi. Jika nilai absorbansi sebelum diinkubasi lebih tinggi dibandingkan nilai absorbansi sesudah diinkubasi maka pertumbuhan bakteri tehambat, dan sebaliknya jika nilai absorbansi sesudah inkubasi lebih tinggi dibandingkan sebelum diinkubasi maka masih terjadi pertumbuhan bakteri. ${ }^{8}$ Inkubasi dilakukan dengan tujuan untuk memantau perkembangan dan pertumbuhan bakteri. $^{9}$

Pada konsentrasi $50 \%$ terjadi penurunan nilai absorban, maka dapat disimpulkan bahwa konsentrasi $50 \%$ merupakan kadar hambat minimum ekstrak buah mengkudu terhadap pertumbuhan bakteri Streptococcus mutans.

Melalui hasil penelitian terdapat perbedaan KHM ekstrak buah mengkudu terhadap pertumbuhan Streptococcus mutans yang dianalisis menggunakan metode turbidimetri dan spektrofotometer UV-Vis. Hal ini dapat disebabkan karena adanya perbedaan prinsip kerja pada masing-masing metode. Pada metode turbidimetri peneliti hanya melihat hasil secara visual, dengan melihat kekeruhan, jadi dapat dikatakan hasilnya cenderung bersifat subjektif. ${ }^{10}$ Spektrofotometer UVVis merupakan salah satu contoh instrumentasi analisis yang digunakan dalam penelitian ini. Alat ini banyak bermanfaat untuk penentuan konsentrasi senyawa-senyawa yang dapat menyerap radiasi pada daerah ultraviolet (200-400 $\mathrm{nm})$. Kelemahan pengujian dengan cara ini ini ialah kesalahan sistematik yang sering terjadi dalam analisis menggunakan spektrofotometer sebagai berikut: ${ }^{11}$

1. Serapan oleh pelarut: Hal ini dapat diatasi dengan penggunaan blangko, yaitu larutan yang berisi matrik selain komponen yang akan dianalisis.

2. Serapan oleh kuvet: Kuvet yang biasa digunakan adalah dari bahan gelas atau kuarsa. Dibandingkan dengan kuvet dari bahan gelas, kuvet kuarsa memberikan kualitas yang lebih baik, namun tentu saja harganya jauh lebih mahal. Serapan oleh kuvet ini diatasi dengan penggunaaan jenis, ukuran, dan bahan kuvet yang sama untuk tempat blangko dan sampel.

3. Kesalahan fotometrik normal pada pengukuran dengan absorbansi sangat rendah atau sangat tingggi, hal ini dapat diatur dengan pengaturan konsentrasi, sesuai dengan kisaran sensitivitas dari alat yang digunakan. (melalui pengenceran atau pemekatan) sama seperti pHmeter, untuk mengatasi kesalahan pada pemakaian spektrofotometer.

Metode spektrofotometer memiliki kekurangan dalam selektivitas untuk membedakan sampel dengan partikelpartikel lain atau kontaminan yang menyerap cahaya dalam panjang gelombang yang sama, namun dengan 
spektrofotometer UV-Vis, hasil yang didapatkan bersifat kuantitaif sehingga dapat dikatakan hasilnya lebih akurat. ${ }^{12}$

Kromatografi Cair Kinerja Tinggi (KCKT) atau High Pressure Liquid Chromatography (HPLC) merupakan salah satu metode kimia dan fisikokimia. KCKT termasuk metode analisis terbaru yaitu suatu teknik kromatografi dengan fasa gerak cairan dan fasa diam cairan atau padat. Banyak kelebihan metode ini jika dibandingkan dengan metode lainnya. ${ }^{13}$ Penelitian yang dilakukan oleh Joshi et al. pada tahun 2010 di India, membandingkan metode spektrofotometri dengan metode KCKT dan didapatkan hasil bahwa metode KCKT memiliki hasil yang lebih baik dari pada metode spektrofotometri dari segi keakuratan, ketelitian, dan sensitivitas dalam membaca nilai absorbansi. ${ }^{14}$

Uji KHM ekstrak buah mengkudu (Morinda citrifolia L.) terhadap pertumbuhan Streptococcus mutans merupakan penelitian baru dan belum pernah dilakukan sebelumnya. Berdasarkan hasil penelitian ini, KHM ekstrak buah mengkudu (Morinda citrifolia L.) terhadap pertumbuhan Streptococcus mutans yaitu konsentrasi $50 \%$, melalui hasil pengukuran spektrofotometri dengan menggunakan alat spektrofotometer UV-Vis.

\section{SIMPULAN}

Konsentrasi hambat minimum ekstrak buah mengkudu (Morinda citrifolia, L) terhadap bakteri Streptococcus mutans terdapat pada konsentrasi $50 \%$.

\section{SARAN}

Dapat dilakukan penelitian mengenai uji konsentrasi hambat minimum (KHM) ekstrak buah mengkudu (Morinda citrifolia L.) terhadap pertumbuhan Streptococcus mutans dengan menggunakan metode Kromatografi Cair Kinerja Tinggi (KCKT) untuk memperoleh hasil yang lebih akurat.

Dapat dilakukan penelitian lebih lanjut mengenai nilai konsentrasi bunuh minimum (KBM) ekstrak buah mengkudu terhadap pertumbuhan Streptococcus mutans.
Dapat dilakukan penelitian mengenai uji konsentrasi hambat minimum (KHM) ekstrak buah mengkudu (Morinda citrifolia L.) terhadap pertumbuhan mikroorganisme rongga mulut lainnya.

\section{DAFTAR PUSTAKA}

1. Hongini SY, Aditiawarman M. Kesehatan Gigi dan Mulut. Bandung: Pustaka Reaka Cipta, 2012.

2. Sumawinata N. Senarai Istilah Kedokteran Gigi Inggris-Indonesia. Jakarta: EGC, 2012; p. 34.

3. BadanPenelitian dan Pengembangan Kesehatan Departemen Kesehatan RI. Riset Kesehatan Dasar (RISKESDAS) 2013. Lampiran laporan Riskesdas 2013. Jakarta, 2013; p. 11-2.

4. Ireland R. Clinical Textbook of Dental Hygiene and Theraphy. WU: Blackwell Munksgaard, 2006; p.77.

5. Angela A. Pencegahan primer pada anak yang berisiko karies tinggi. Maj Ked Gigi (Dent J). 2005;38(3):130.

6. Malinggas F. Uji daya hambat ekstrak biji buah mengkudu ( $M$ citrofolia L) terhadap pertumbuhan Streptococcus mutans secara in vitro [Skripsi], Manado: Program Studi Pendidikan Dokter Gigi Fakultas Kedokteran Universitas Sam Ratulangi; 2015.

7. Cockerill FR, Wikler MA, Alder J, Dudley MN, Eliopoulos MN, Ferraro MJ, et al. Methods for Dilution Antimicrobial Susceptibility Tests for Bacteria that Grow Aerobically; Approved Standard-9th ed. CLSI Document M07-A9. Wayne, PA: Clinical and Laboratory Standards Institute, 2012; p. 17.

8. Sitompul R. Uji konsentrasi hambat minimum (KHM) ekstrak daun gedi (Abelmoschus manihot L. Medik) terhadap pertumbuhan Staphylococcus aureus. Dentire. 2016;5(1):21-7.

9. Harti SA. Mikrobiologi Kesehatan; Peran mikrobiologi dalam bidang kesehatan (1st ed). Yogyakarta: Graha Ilmu, 2009; p. 124-6.

10. Septian K. Uji konsentrasi hambat minimum (KHM) ekstrak spons laut Callyspongia sp. terhadap pertumbuhan Staphylococcus aureus. Dentire. 2016;5(1):5-10.

11. Watson DG. Pharmaceutical analysis (2nd 
ed). London: Elsevier, 2005; p. 88.

12. Geisler J, Thompson T. Choosing the best detection method: Absorbance vs. Fluorescence. Biocompare, September 2016; p. 9-16.

13. Putra EDL. Kromatografi Cair Kinerja Tinggi dalam Bidang Farmasi. Medan; Universitas Sumatera Utara; 2004; p.
$1-2$.

14. Joshi HR, Patel AH, Captain AD. Spectrophotometric and reversedphase high-performance liquid chromatographic method for determination of doxophylline in pharmaceutical formulation. J Young Pharm. 2010;2(3):289-96. 